\title{
Factors Affecting Saudi Consumer Trust in E-commerce: A Quantitative Analysis
}

\author{
Bandar Alkhalil \\ Information System department \\ Faculty of Computing \& Information Technology \\ King Abdulaziz University \\ Jeddah, Saudi Arabia
}

\author{
Muazzam Siddiqui \\ Information System department \\ Faculty of Computing \& Information Technology \\ King Abdulaziz University \\ Jeddah, Saudi Arabia
}

\begin{abstract}
E-commerce has become one of the best significant businesses around the world. The tremendous development in online shopping makes the business easy to be global and increase the market segmentation for customer's demand. In World Wide Web huge e-commerce their owners in different geographical. So, this the paper focuses on identifying the main influencing factors on trust for e-commerce based on previous studies and result survey questionnaire. The result of this study clearly shows that which factor is more efficient on trust in e-commerce based on random sample customers in Saudi Arabia.
\end{abstract}

\section{Keywords}

E-commerce, Trust, Customer Trust, Electronic commerce, Saudi Arabia, Critical Factors, B2C e-commerce, Online customers, Factors.

\section{INTRODUCTION}

Building a trust between buyers and sellers is one of the essential concepts that lead to the success of e-commerce. However, building trust in e-commerce is a complicated task because of multiple reasons. First, it is not relying on the customers there are various parties involved in successful ecommerce transactions like IT infrastructure and other digital components. Second, customers come from different cultures with different characteristics, so factors that influencing the customers' trust may be varied depending on the customer's culture and characteristics. The stakeholders of this study are the customers from Saudi Arabia since the authors believe that the factors influencing trust will be different compared to another country. The tremendous development of Saudi Arabia in the e-commerce so, the trust in E-commerce their owners in Saudi Arabia it was solved in MAROOF service. There is an urgent need to discuss the most important factors that affect consumers' trust in Saudi Arabia. This paper focuses on e-commerce their owner abroad and the trust factors consumers in Saudi Arabia. Also, the paper will be an important reference for investors who want to invest in ecommerce and their main consumers are located in Saudi Arabia to get their attention to these important factors.

\section{E-COMMERCE}

In E-commerce, there is no need for a direct relationship between parties to the business process. Also, in online operations, there is no need for the paper to perform operations, where all processes are automated such as delivery and payment, are done with a few clicks through the World Wide Web. Both the ends of the business process (seller/buyer) will end with the use of e-commerce technique. Therefore, the following points highlight some of the advantages in E-commerce for both customers and business owners.

\subsection{Advantages for The Business Owners}

1. Effective communication with customers crossing the border and exchanged information with them.

2. Customer satisfaction.

3. A reduction in facility expenses, costs of operation and maintenance of websites.

4. More economically than the physical store.

\subsection{Advantages for The Customers}

1. Saving time, money and effort in search and access to many services.

2. Benefit from the comments or evaluate of excustomers.

3. Customers can interact with more than one source or a party at the same time

\section{E-COMMERCE IN GCC}

There is a noticeable increase in the interest in e-commerce because the majority of Arab countries joining the World Trade Organization. The result of this join, most of the foreign companies can engage the local e-commerce market this will increase the competition between the local and foreign companies. GCC market is considered as one of the best markets globally, especially in the purchasing power. Saudi Arabia is considered one of the biggest countries in the economic growth and use of information technology. Also, the Saudi markets have the highest level of sales in hardware and software in the area.

\section{TRUST}

Recently, with the spread of the Internet user in the world, the e-commerce term has appeared, where investors can engage their business and promote their goods and products around the world easily. There are many factors that contribute to the success of electronic commerce. The most important factor is the trust that is built between sellers and buyers in the electronic market. Based on the literature review, in order to increase confidence among the sellers and the buyers in the electronic markets, there are many influencing factors must be considered. These factors affect the trust of the customers and the business owners. However, in order to increase the level of trust, it better to define the trust based on different disciplines of philosophy, psychology, management, and marketing to understand exactly what trust exactly means.

\subsection{Trust in General}

According to [1], trust is defined as "to believe that someone is good and honest and will not harm you, or that something is 
safe and reliable". In [2], trust is defined as "Firm belief in the reliability, truth, or ability of someone or something"

\subsection{Psychology}

In the psychological, some researchers like [3] and his participants in research they defined the trust as "Trust is a psychological state comprising the intention to accept vulnerability based upon positive expectations of the intentions or behavior of another". [4] and his participants in research they defined trust as "an individual's belief in, and willingness to act on the basis of, the words, actions, and decisions of another".

\subsection{Sociological}

In the sociological discipline, [5] have studied the trust from the view of social relationships that are conducted between people. On the other hand, [6] have defined the trust as "an essential element in any relationship and without trust; modern society would not be possible".

\subsection{Management}

In the management discipline, some researchers like [7] they defined trust as "the belief that the decision makers will produce outcomes favorable to the personal interests without any influence by the person".

\subsection{Marketing}

In the marketing discipline, building trust with the consumers is essential to the success of the advertising agencies. Some researchers like [8] he is not considered the trust as a basis for success but they considered the trust as a tool that helps a company and organization to achieve their goals and to increase the revenue.

\section{LITERATURE REVIEW}

One of the most important challenges faced by sellers and buyers in e-commerce is the trust issue. Increasing customer trust in e-commerce has become an essential issue for continuity of e-commerce. In order to increase trust, it is better to identify factors influencing trust. According to [9] they addressed three important factors influencing the level of trust between sellers and buyers in the online market. This level of trust includes security of online transaction processing systems, the privacy of personal information, trust and reliability of online vendors. In [10] they more emphasized the importance of these factors. Also, [11] they clarified the importance of vendor reputation, perceived site quality as important factors. In addition, [12] studied 27 factors that play a major role in trust. However, he investigated that the advertisement with 3 variables advertising in other media, and satisfaction and a good evaluation of past consumers as an important factor that is not covered in the literature. Moreover, [13] considered the feedbacks as an important factor to determine credibility and reliability of sellers and buyers. Also, [7] considered the design as a key factor to increase customer trust in e-commerce. In [14] the vendor in e-commerce has nothing to gain by cheating. The trust built based connection to the customers and the familiarity with evendor. Also, the structural assurance was a precursor to trust and was essential in online situations.

According to [15] they categorized the trust into two kinds of trust in members and trust in service providers. The trust in member would be a paramount importance aspect if the customers attended to exchange of information than trust in the service provider. In contrast, the trust in the service provider would be more significant than the trust in member if the customer attended to purchase online. In [16] they categorized the factors influencing the trust into two main categories. First, internal factors that come from the actors with the transaction like (consumer characteristics, website characteristics and firm characteristics). Second, external factors that provide the support to the transaction to complete like (policy, technology).

Influencing factors vary based on the different geographical location. [17] Authors identified seven factors affecting the consumer to trust e-commerce. Authors introduced their hypotheses to increase trust in e-commerce. To assess the research model, the authors used the survey approach. The data was collected from the Internet users in New Zealand. The authors found that customers did online shopping if they felt a high degree of trust in e-business and they know how to use the web. The market orientation of this model is ambiguous and need more investigation. China has the greatest e-commerce market in the world.

In [18] they examined three very successful online companies (360buy, Taobao, Yihaodian) in China. Authors introduced their hypotheses then discussed experiments in China, Germany, United States, and Singapore. Generally, they found that vendor reputation had the most important effect on consumers regarding online shopping in China and other countries. As in [19] a prototype e-commerce data service for trustworthiness developed for a project propped by "China Ministry of Business". The paper showed a framework evaluation composed of two models trustworthiness and an evaluation. Trustworthiness model defined evaluation subject, factors, and indicator trust then the value scope of the indicator. The evaluation model includes evaluation of principle, tools, and related work then manipulates worthiness, apply service and display style.

In [20], they proposed a framework that contains an analysis of e-service quality and factors for pixieindy.com. Authors used a questionnaire method based on "ES-QUAL and ESREC-QUAL". [21]; [22] they used qualitative analyses in interview form with open-ended questions structure. In Saudi Arabia, Authors discussed factors easy interface, clear navigation and procedure effect on the customer trust in positive perception. In India, authors focused on students' behavior buying online. They selected 25 college students' graduate and postgraduate from different levels in "So-Maiya Vidyavihar Campus, in Vidyavihar, Mumbai". Some of the ecommerce has excellent platform contain large numbers of buyers and sellers in different geographic regions like Amazon. [23] authors proposed to build a navigation model to help users how to trust in certain product or buyers by analyzing their online reviews. They parse opinion sentences then implement semantic analysis at sentence level for customer's reviews (positive or negative). After that ranking evaluates trust. In the end, experimental results show that the proposed process is highly effective.

Regarding previous literature reviews that discussed trust as an influencing factor, it has been noticed that there are different arguments in most influencing factors toward the trust aspect in e-commerce. This paper mainly addresses the factors influencing the trust level of the customer in ecommerce in Saudi Arabia. The consumer is considered the main stakeholder in this research since the research employs a single data collection method that is quantitative approach through survey questionnaires. This method will help the researcher Identifies significant factors influencing the level of trust in e-commerce in Saudi Arabia. 


\section{RESEARCH METHODOLOGY}

In order to the outcome the objectives of this research and answer the research questions primary research questions which is "What are the most critical factors that influencing the trust of consumers in e-commerce in Saudi Arabia from the consumer perspective", the research employed the quantitative approach. Data of this research gathered via survey questionnaire. The data collected from e-commerce consumers in different parts of Saudi Arabia. The questionnaire consists of two parts. The first part of questions collected the personal information such as (gender, age, career, internet experience, a frequency of online purchase and money spent on the purchase. The second part of questions consisted of 11 variables as shown in Figure 1 that factors influencing the level of trust in e-commerce. These factors indicated the primary factors of consumers depending on online purchasing in Saudi Arabia. In this part, all variables will be in scales ranging from 5 (strongly agree) to 1 (strongly disagree). While the research framework In this research, there are many steps that must be taken to reach the desired results as shown in Figure 2.

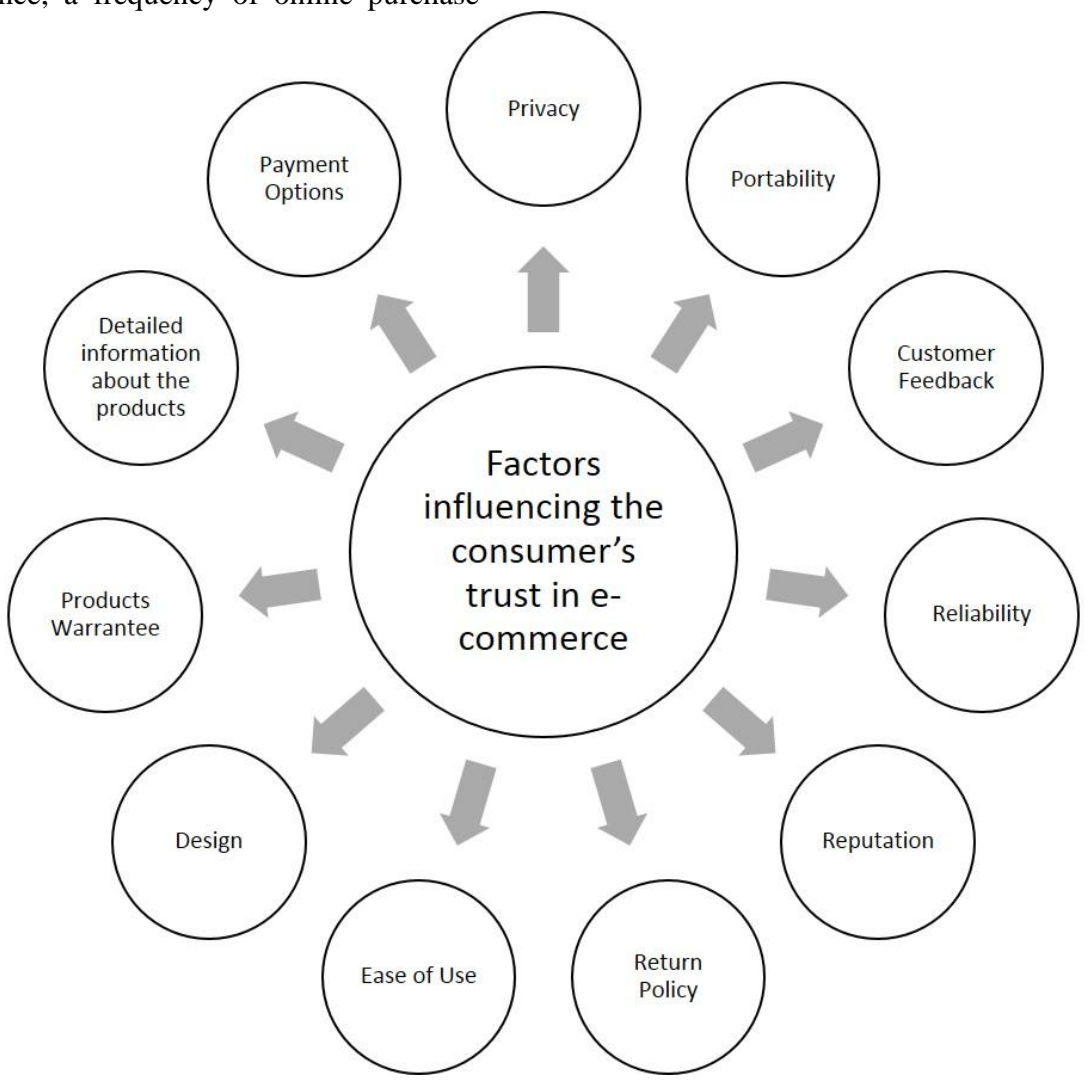

Fig 1: Factors Influencing The Consumer Trust

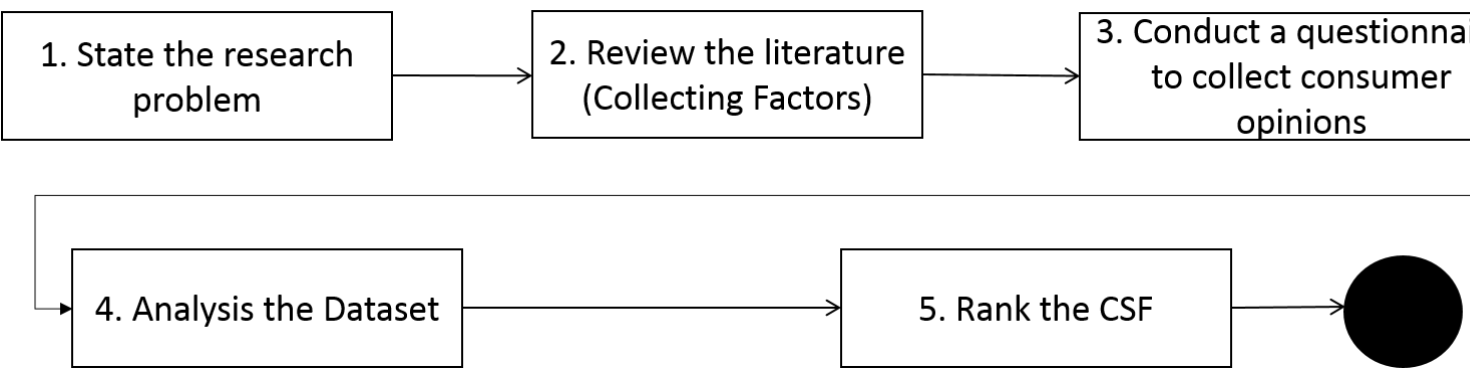

Fig 2: Research Framework

\section{DATA ANALYSIS}

In this paper, this survey was established in order to collect customer respondents about the most influencing factors that affect trust in an e-commerce environment. In this study, over 1000 questionnaires were distributed. Out of the over 1000 distributed questionnaire in this study. A total of 280 questionnaires were received that used for this study. $56.3 \%$ of the responses were female, and $43.7 \%$ were male. The majority of the respondent's ages between 20 or 30 . About $53 \%$ of the respondents were a student while $30 \%$ of respondents were employees. The majority of respondents are annually buying electronic stuff as resulted that $45 \%$ of the respondents while those who are buying monthly were about thirty-one percent of the respondents. Finally, the most responses resulted that the average expenses of online purchases are between 500 SR and 1000 SR while about $32 \%$ of responses resulted that expenses less than 500 SR. The detailed descriptive statistics of the responses are shown in table 1 as following. 
Table 1: Descriptive statistics of respondents

\begin{tabular}{|c|c|c|}
\hline Measure & Item & Percent \\
\hline \multirow{2}{*}{ Gender } & Male & 43.7 \\
\hline & Female & 56.3 \\
\hline \multirow{5}{*}{ Age } & $<20$ & 32.3 \\
\hline & $20-29$ & 40.1 \\
\hline & $30-39$ & 21.9 \\
\hline & $40-49$ & 3.9 \\
\hline & $>50$ & 1.8 \\
\hline \multirow{5}{*}{ Career } & Student & 53.8 \\
\hline & Employee & 30.5 \\
\hline & Business Owner & 2.15 \\
\hline & Unemployed & 12.2 \\
\hline & Other & 1.35 \\
\hline \multirow{5}{*}{$\begin{array}{l}\text { Frequency of } \\
\text { online purchases }\end{array}$} & Daily & 0 \\
\hline & Weekly & 2.5 \\
\hline & Monthly & 31.5 \\
\hline & Yearly & 45.2 \\
\hline & Never & 20.8 \\
\hline \multirow{7}{*}{$\begin{array}{l}\text { Money spent on } \\
\text { online purchases }\end{array}$} & $<500 \mathrm{SR}$ & 32.6 \\
\hline & $500 \mathrm{SR}-1000 \mathrm{SR}$ & 34.3 \\
\hline & $1001 \mathrm{SR}-3000 \mathrm{SR}$ & 7.8 \\
\hline & $3001 \mathrm{SR}-5000 \mathrm{SR}$ & 4.3 \\
\hline & $5001 \mathrm{SR}-10.000 \mathrm{SR}$ & 1.1 \\
\hline & $>10.000 \mathrm{SR}$ & 0.6 \\
\hline & Never & 19.3 \\
\hline
\end{tabular}

\section{RESULTS}

The result of the study clearly shows that the important factors influencing customer trust in e-commerce are about eleven factors. Four influential factors in the trust of the eleven factors have received the highest respondents attentions which are the return and replacing policy, availability of several payment methods, availability of detailed information about products and providing a guarantee on the online store products. In the return policy factor, $61.3 \%$ of the respondents were strongly agreed to deal with the online store that enables the customers to return or replace the products after purchase. Availability of several payment methods factor resulted around $48.7 \%$ of the respondents are strongly agreed to deal with the online store if there were more options to pay. Also, the providing detailed information about the products on the online store will increase the trust of customer what confirms that is $48 \%$ of the respondents will deal with the online store if detail information about the product were provided. In addition, the factor of providing a warranty on the products highlighted an important entity that should be provided in electronic stores to increase the trust of the customers. This is confirmed by the questionnaire as resulted that $44.8 \%$ of the respondents will deal with the online store if there was a warranty for the purchased products. Also, The result of this study shows that a good reputation of the online store, privacy, feedback, availability of the online store, ease of use, design, and portability are important factors to build a suitable trust with the customer as shown in detail in the table below:

Table 2: Factors Ranking Results

\begin{tabular}{|c|c|c|}
\hline Factor & $\begin{array}{c}\text { Selected by \% of } \\
\text { respondents }\end{array}$ & Rank \\
\hline Return Policy & $61.3 \%$ & 1 \\
\hline $\begin{array}{c}\text { Multiple payment Options } \\
\text { Detailed information about } \\
\text { the products }\end{array}$ & $48.7 \%$ & 2 \\
\hline Products Warrantee & $48 \%$ & 3 \\
\hline Reputation & $40.5 \%$ & 5 \\
\hline Ease of use & $39.4 \%$ & 6 \\
\hline Feedback & $38.4 \%$ & 7 \\
\hline Privacy & $38 \%$ & 8 \\
\hline Design & $21.9 \%$ & 9 \\
\hline Portability & $16.8 \%$ & 10 \\
\hline Reliability & $10.8 \%$ & 11 \\
\hline
\end{tabular}

The result of the study clearly shows that the important factors influencing customer trust in the e-commerce and their effect on the customers trust in numbers. Therefore, the online store owners have to pay more attention to these factors to increase the trust. The result of this study shows that the policy of the online store, availability of several payment methods, availability of detailed information about products, and products' warranty, store reputation and ease of use are primary factors to building a good trust with the customer. However, customer feedback, privacy, store design, portability and store reliability are considered to be less important than previous factors in building trust with customers as discussed in the data analysis section.

\section{CONCLUSION AND FUTURE WORK}

E-commerce becomes an important business around the world. The great development in online shopping makes the business easy to be global and increase the market segmentation for customers demand. Recent years, the demands on e-commerce market in the world increasing. Business to Consumer (B2C) in e-commerce requires the most critical key consumers' trust. Trust has been identified as one of the most challenging barriers to people for engaging in ecommerce. E-commerce is tenuous without a general climate of online trust. 
In this paper, an attempt was made to identify the factors that Influence the trust of a Saudi Arabian consumer using ecommerce. From the previous work identified the main influencing factors trust for e-commerce identified as security, privacy, feedback, reputation, product guarantee, availability, ease of use, content, design, policy, and portability. The funding from the questionnaire to know the priority of consumers to trust in e-commerce. Also, this paper will be a worthy reference for investors who want to invest in ecommerce and their main consumers are located in Saudi Arabia to get their attention to these important factors. The paper lacks to limited sample according to a huge population in Saudi Arabia. The further work will be in semi-interviews to get more scientific and accurate result. Also, at the business side making interviews with successful e-commerce companies in Saudi Arabia.

\section{REFERENCES}

[1] Dictionary, C (2017). Trust Meaning in the Cambridge English Dictionary. http://dictionary.cambridge.org/dictionary/english/trust/. [Online; accessed 15-feb-2017].

[2] Dictionary, O (2017). Trust Meaning in the Oxford English Dictionary. https://en.oxforddictionaries.com/definition/trust/. [Online; accessed 17-feb-2017].

[3] Rousseau, D. M., Sitkin, S. B., Burt, R. S., and Camerer, C. (1998). Not so different after all: A cross-discipline view of trust. Academy of management review, 23(3):393404.

[4] Lewicki, R. J., McAllister, D. J., and Bies, R. J. (1998). Trust and distrust: New relationships and realities. Academy of management Review, 23(3):438-458.

[5] Barber, B. (1983). The logic and limits of trust. new Brunswick.

[6] Macy, M. W. and Skvoretz, J. (1998). The evolution of trust and cooperation between strangers: A computational model. American Sociological Review, pages 638-660.

[7] Wang, Y. D. and Emurian, H. H. (2005). An overview of online trust: Concepts, elements, and implications. Computers in human behavior, 21(1):105-125.

[8] Kumar, N. (1996). The power of trust in manufacturerretailer relationships. Harvard business review, 74(6):92.

[9] Thaw, Y. Y., Mahmood, A. K., and Dominic, P. (2009). A study on the factors that influence the consumers trust on ecommerce adoption. arXiv preprintarXiv:0909.1145.

[10] Susanto, H. A. and Chang, Y. (2014). Determinants of initial trust formation in electronic commerce acceptance in Indonesia. In Systems, Process and Control (ICSPC), 2014 IEEE Conference on, pages 96-100. IEEE.

[11] McKnight, D. H., Choudhury, V., and Kacmar, C. (2002). The impact of initial consumer trust on intentions to transact with a web site: a trust building model. The Journal of Strategic Information Systems, 11(3):297-323.
[12] Maadi, M., Maadi, M., and Javidnia, M. (2016). Identification of factors influencing building initial trust in e-commerce. Iranian Journal of Management Studies.

[13] Chong, S. K. and Abawajy, J. (2012). E-commerce trust management system reliability. In Information Science and Service Science and Data Mining (ISSDM), 2012 6th International Conference on New Trends in, pages 13-18. IEEE.

[14] Gefen, D., Karahanna, E., and Straub, D. W. (2003). Trust and tam in online shopping: an integrated model. MIS quarterly, 27(1):51-90.

[15] Lee, H. Y., Ahn, H., and Han, I. (2006). Analysis of trust in the e-commerce adoption. In Proceedings of the 39th Annual Hawaii International Conference on System Sciences (HICSS'06), volume 6, pages 113c-113c. IEEE.

[16] Franco, D. P. (2014). Factors and models analysis of consumer trust on e-commerce-doi (http://dx. doi. org/10.17800/2238-8893/aos. v3n1p111-120). Amazônia, Organizações e Sustentabilidade, 3(1):111120.

[17] Corbitt, B. J., Thanasankit, T., and Yi, H. (2003). Trust and e-commerce: a study of consumer perceptions. Electronic commerce research and applications, 2(3):203-215.

[18] Clemons, E. K., Jin, F., Wilson, J., Ren, F., Matt, C., Hess, T., and Koh, N. (2013). The role of trust in successful ecommerce websites in china: Field observations and experimental studies. In System Sciences (HICSS), 2013 46th Hawaii International Conference on, pages 40024011. IEEE

[19] Li, Y., Zhou, F., Li, J., Liao, Y., and Chai, Y. (2013). Trustworthiness evaluation of registered information in a trusted e-commerce data service. In e-Business Engineering (ICEBE), 2013 IEEE 10th International Conference on, pages 353-357. IEEE.

[20] Panya, A. and Ramingwong, L. (2014). A framework for building trust in b2c e-commerce based on consumer's viewpoint in Thailand. In The 20th Asia-Pacific Conference on Communication (APCC2014), pages 271276. IEEE.

[21] AKHTER, F. and ALBALAWI, W. (2016). Online trust and young entrepreneurs: A case of Saudi Arabia. Journal of Theoretical \& Applied Information Technology, 86(1).

[22] Jadhav, V. and Khanna, M. (2016). Factors influencing online buying behavior of college students: A qualitative analysis. The Qualitative Report, 21(1):1.

[23] Zhu, Q. (2010). Trust service discovery by opinions classification on virtual communities. In Networks Security Wireless Communications and Trusted Computing (NSWCTC), 2010 Second International Conference on, volume 1, pages 281-284. IEEE. 